\title{
Organization
}

\section{Governing impaired jobseekers in neoliberal societies - from sheltered employment to individual placement}

\begin{tabular}{|r|l|}
\hline Journal: & Organization \\
\hline Manuscript ID & ORG-18-0132.R3 \\
\hline Keywords: & Neoliberal governmentality, Post-disciplinary control, Ableism, Disability \\
\hline Abstract: & $\begin{array}{l}\text { This paper accounts for a study of the largest employer in Scandinavia of } \\
\text { jobseekers with designated impairments. Like many similar } \\
\text { organizations, this organization has undergone a transformation from a } \\
\text { provider of "sheltered work programs", which remove this category of } \\
\text { jobseekers from the labour market, to a provider of "individual } \\
\text { placement programs", which instead integrates them in the labour } \\
\text { market. I use Foucauldian governmentality studies to show how this } \\
\text { transformation problematizes basic assumptions underlying } \\
\text { organizational disability studies. While these studies are variegated, they } \\
\text { have generally found that jobseekers with designated impairments are } \\
\text { often treated as disabled, as less employable than non-impaired } \\
\text { individuals and in need of care and rehabilitation. The study presented } \\
\text { below points in another direction. It shows that jobseekers' designated } \\
\text { impairments are treated as signs of their special abilities for particular } \\
\text { jobs, rather than as signs of their disabilities. These findings, I argue, } \\
\text { are illustrative of how a neoliberal governmentality tends towards } \\
\text { replacing the distinction between the able and the disable with a bio- } \\
\text { medical structuring of different qualities of human capital. While it leads } \\
\text { to that individuals with impairments are integrated in the labour market, } \\
\text { I argue that it also leads to that they are treated as having an exclusive, } \\
\text { medically designated fit for simple and often dirty labour. }\end{array}$ \\
\hline mation \\
\hline
\end{tabular}

\section{SCHOLARONE Manuscripts}




\section{Governing impaired jobseekers in neoliberal societies - from sheltered employment to individual placement}

This paper accounts for a study of the largest employer in Scandinavia of jobseekers with designated impairments. Like many similar organizations, this organization has undergone a transformation from a provider of "sheltered work programs", which remove this category of jobseekers from the labour market, to a provider of "individual placement programs", which instead integrates them in the labour market. I use Foucauldian governmentality studies to show how this transformation problematizes basic assumptions underlying organizational disability studies. While these studies are variegated, they have generally found that jobseekers with designated impairments are often treated as disabled, as less employable than non-impaired individuals and in need of care and rehabilitation. The study presented below points in another direction. It shows that jobseekers' designated impairments are treated as signs of their special abilities for particular jobs, rather than as signs of their disabilities. These findings, I argue, are illustrative of how a neoliberal governmentality tends towards replacing the distinction between the able and the disable with a bio-medical structuring of different qualities of human capital. While it leads to that individuals with impairments are integrated in the labour market, I argue that it also leads to that they are treated as having an exclusive, medically designated fit for simple and often dirty labour. Key words: disability, ableism, neoliberal governmentality, post-disciplinary control 
This paper accounts for a study of the largest employer in Scandinavia of jobseekers with designated impairments. The organization, Samhall, has undergone a major transformation, from a provider of "sheltered work programs" (Holmqvist, 2005), which remove and temporarily protect impaired jobseekers from the labour market, to a provider of "individual placement programs", which seek to integrate this category of jobseekers in the labour market.

I draw on Foucault's (2007: 2008) and 'Foucauldians' within sociology's (e.g. Dean, 1999: 2015; Miller and Rose, 2008; Rose, 1999: 2007) studies to show how the transformation from sheltered employment programs to individual placement programs represents an interesting example of what this research refers to as a shift from liberal to neoliberal governmentality and from disciplinary to post-disciplinary regulation. Furthermore, I show how these shifts problematize basic assumptions of organisational disability studies (e.g. Corlett and Williams, 2011; Foster and Wass, 2013; Author et al., 2013; Lindsay et al., 2014; Vanderkinderen et al., 2012; Williams and Marvin, 2012).

Organizational disability studies comprise several research strands. They all build on a more or less pronounced distinction between impairments and disabilities. Yet, whereas some understand disabilities as caused by impairments, others emphasize that there is no inevitable connection between impairments and disabilities; that individuals with impairments emerge as disabled is to them a consequence of the social and material conditions surrounding these individuals. Nevertheless, organizational disability studies have generally found that individuals with impairments are often treated as disabled, less employable and in need of protection and correction.

Below I show how these findings and assumptions relate to the specific politicaleconomic approach that Foucauldian research refers to as liberal governmentality. More 
specifically, I show how they relate to the liberal-governmental distinction between those that manage to live and work via markets and those who require protection and correction in disciplinary institutions such as sheltered work programs.

The findings of this study point in a direction, which indicates how these liberal governmental principles are beginning to change and, as a result, how basic assumptions of organizational disability studies ought to be changed. They show that jobseekers who lack social skills and cultural fit are increasingly designated as impaired and, on this basis, how they are managed as especially able of handling the specific jobs they are offered. That is, their designated impairments are treated as signs, not of disabilities and neither of their need for sheltered protection from the labour market, but of their special and superior abilities of handling specific jobs in the labour market. This logic, I argue, is illustrative of how a neoliberal governmentality and post-disciplinary control tend towards replacing the distinction between the able and the disable with a bio-medical structuring of different qualities of human capital.

By way of this analysis the paper contributes to organizational disability studies in two respects: It outlines how a neoliberal governmentality is implicated in the construction of new types of impaired jobseekers. Furthermore, it provides an example of a postdisciplinary program that shows how these jobseekers are regulated, not as disabled, but as specifically able and suitable for jobs that non-impaired jobseekers do not want and therefore are considered unsuitable for.

Below I outline the different strands of organizational disability research. Thereafter I develop the notions of neoliberal governmentality and post-disciplinary control and show how they relate to the basic assumptions of this literature. On this basis, I turn to the study of Samhall. The paper is ended with a discussion and conclusions. 


\section{Organizational disability studies}

In organizational disability studies we can, broadly, discern three underlying models of thought: a medical model, a social model and a critical model (Thanem, 2008; Shakespeare, 2006; Williams and Mavin, 2012). In all three models the distinction between impairments and disabilities is more or less fundamental. However, the models differ considerably in how they understand the two notions and the connections between them. The medical model uses the notion of impairment to refer to individual's physical and/or mental restrictions. Furthermore, it assumes that disabilities are caused by these impairments. Research based on the medical model is thus primarily concerned with the detection, categorization and possible avoidance of impairments and with how people who are disabled can be rehabilitated through medical and psychological treatment (Colella and Stone, 2005; Stone and Colella, 1996).

The social model (Abberley, 2002; Barnes and Mercer, 2005; Foster, 2007; Thomas, 2004) was coined by Oliver (1990) on the basis of ideas, which formed in the 1970s within the UK Union of the Physically Impaired Against Segregation. The social model does not question the idea that individuals have physical and/or mental impairments. Yet, it questions the causality between impairments and disabilities assumed by the medical model (Barnes and Mercer, 2005; Thomas, 2004). It assumes that impairments are not in themselves disabling. More specifically, it defines disability as social oppression caused by social and material barriers in the environment (Abberley, 2002; Barnes and Mercer, 2005; Lindsay et al., 2014; Vanderkinderen et al., 2012). This means that disability is alleged of being socially constructed. Furthermore, it means that disability is not seen as an inevitable issue of impaired individuals' lives, but an issue which can be resolved by redesigning jobs with consideration for impaired individuals and by changing co-workers and employers stereotyped views of them as less productive. Hence, to the extent the individual/medical 
model offers an individual deficit explanation for disability, the social model offers a socialpolitical explanation (Tregaskis, 2004).

The critical model is not really a model, but a collection of different strings of research that have developed at the intersection of phenomenology, feminism and poststructuralism as critiques and problematizations of both the medical and the social models of disability (Author et al. 2013; Campbell, 2009; Foster and Wass, 2013; Goodley, 2014; Holmqvist, 2009; Jammears et al. 2016; Mik-Meyer, 2016; Shakespeare, 2006; Thanem, 2008; Williams and Mavin, 2012).

More specifically, critical researchers argue that disability studies have maintained a too narrow focus. To grasp more fully how and why individuals come forth as disabled, it is alleged that disability studies need to take a broader view and consider how general ideals and their materialization in work and life indirectly affect impaired individuals by potentially making them up as "other" than normal (cf. Mik-Meyer, 2016). To frame this approach, critical disability researchers use the term "ableism" (e.g. Campbell, 2009; Foster and Wass, 2012; Jammears et al., 2016; Nik-Meyer, 2016; Williams and Mavin, 2012), which refers to "ideas, practices, institutions and social relations that presume able-bodiedness, and by so doing, construct ... [disabled people] ... as marginalized others" (Chouinard, 1997: p.380). In one sense, the notion of ableism has been used to broaden and deepen the social model's critique of the medical model. In another sense, however, it has also been used to criticize the social model for its alleged failure to acknowledge the socially constructed nature of impairments. Today, critical researchers suggest, individuals who fail to match ableist ideals are constructed as impaired by governmental processes for the sake achieving political ends such as reducing unemployment (e.g. by legitimating subsidized employments) and creating markets for enterprises that support individuals with designated impairments 
(Author, et al., 2013; Goodley, 2014; Holmqvist, 2009; Jammaers et al., 2016; Tremain, 2015). While the social model, critical researchers argue, has 'demedicalized' disability by showing how it is socially constructed, its failure to consider how individuals become designated as impaired has left the impaired body the exclusive jurisdiction of medical interpretation (Author, et al., 2013; Holmqvist, 2009; Tremain, 2015).

Hence, the social and medical models alike, critical researchers argue, have failed to analyse how bio-medical practices are complicit in the historical emergence of the category of impairment and contribute to its persistence (Goodley, 2014; Tremain, 2015). This, critical researchers emphasize, is not to say that disabilities and impairments are disembodied phenomena, signalling merely social oppression (cf. Shakespeare, 2006; Thanem, 2008; Williams and Mavin, 2012). Quite the contrary, for instance via the notion of "impairment effects" (Williams and Mavin, 2012) it has been a way of pointing towards how individuals' experiences of their bodily or cognitive variations interlock with the fact that these variations are designated as impairments and disabilities.

By drawing attention to how the ontology of disabilities and impairments relates to governmental processes and ableist ideals, the critical model has significantly refined the theoretical assumptions of the two other models. Below I seek to contribute to this refinement by turning to an issue which has been discussed by a few critical scholars (e.g. Barnes and Mercer, 2005; Goodley, 2014; Jammaers et al., 2016; Tremain, 2015), but which has still received relatively little attention: How neoliberalism transforms ableist ideals and thus the meaning, evaluation and regulation of individual's with designated impairments in labour markets. 
Goodley (2014) has touched upon the first part of this issue, i.e. how neoliberalism transforms ableist ideals. He highlights three aspects: It idealizes flexible, selfgoverning individuals who relate to their whole selves - and not just their professional careers and skills - as entrepreneurial businesses. Second, it idealizes individuals who relate to themselves as provisional enterprises (works in progress) and are able to care for and repair themselves at will. Third, it idealizes individuals with specific cognitive and affective abilities; the idealized individual is not merely intellectually gifted, he or she has an active, social and opportune mindset, which is oriented towards what is marketable, new, innovative, etc.

As will be seen, Goodley's (2014) outline of neoliberal ableism captures well the employability ideals that implicitly comes to the fore in the study accounted for below. Yet, Goodley (2014) does not address how neoliberal ableism relates to neoliberal governmentality, i.e. to the partly new ways of rationalizing the government of individuals and markets that comes with neoliberalism. Hereby, I argue, Goodley (2014) is led back towards the conventional assumption in organizational disability studies. Namely, that those who fail to match (neoliberal) ableist ideals are treated as "disabled individuals ... who are either subjected to traditional forms of care administered by a neoliberal workforce (Soldatic and Meekosha, 2012) or, frankly, abandoned" (Goodley, 2014: 31).

The study accounted for below tells a different story. To be able to put this story into a broader context I will turn to Foucauldian governmentality studies. More specifically, I first account for the notions of liberal governmentality and disciplinary regulation in order to contextualize organizational disability studies; i.e. to show in which governmental context the basic assumptions of organizational disability studies have matured. Thereafter I account for neoliberal governmentality and show how it refines liberal ableism, how it opens for new forms of impairments and ways of regulating individuals that have them. 


\section{From liberal governmentality...}

According to Foucault (2007), a liberal governmentality is characterized by its ambiguous attitude towards a market driven economy. Influenced by Adam Smith's (1776/1977) understanding of the market as at once a natural good, which enables just exchange between people, and a force that risks sundering the social foundations of societies, a liberal governmentality pushes in two directions at once. On the one hand, towards regulations, which enable a society that is propelled by a free, competitive market. On the other hand, towards regulations, which protect "the impaired", "the elderly", "the sick", "the unemployed", etc., and ultimately, society as such, from the selfishness of a competitive, market driven economy (see Dean and Villadsen, 2016; Munro, 2012). Hence, a liberal governmentality gives rise to societies that separate between the economic and the social sphere and thus between those who are able to live and work via markets and those who require protection from them.

This implies a particular ableism. A liberal governmentality idealizes "the autonomous employee" (Gershon, 2011). A person who is firmly grounded in the economic sphere, but is able to switch readily between the economic and the social: An individual that capably conducts her body and its capacities to labour as an employable property during the working day and as a civil and solidary member of society after the working day has ended (Gershon 2011). More important to our concerns: it line with the basic assumptions of organizational disability studies (cf. Barnes and Mercer, 2005; Campbell, 2009; Foster, 2007; Holmqvist, 2005; Oliver, 1990) it implies that those who fail to match ableist ideals tend to be treated as disabled, in need of protection and correction. 


\section{...and disciplinary regulation...}

The social and material realization of this ambition of upholding a boundary between economic (individual) rationality and social solidarity, between the able and those who are considered unable (impaired, disabled, old, etc.) and in need of protection and correction, is intimately related to disciplinary institutions (Dean, 1999; Foucault, 2007; Rose, 1996). Disciplinary institutions are built around "dividing practices" (Tremain, 2015). That is, examination techniques, which make use of scientific discourse to categorize individuals and correct their conduct in accordance with the institution's collective norms.

Whereas disciplinary institutions of the early liberal era were undifferentiated, seeking to make up "docile", "machine-like" individuals (Foucault, 1977, p. 135) who accepted crude factory conditions, those of the $20^{\text {th }}$ century became increasingly differentiated. They were found on both sides of the labour market. Factories and offices sought to discipline individuals (prepared by the disciplinary school-system) who conducted themselves as idealized, "autonomous employees" (Covaleski et al., 1998; Gherson, 2011; Townley, 1993). Protective and corrective institutions such as sheltered workshops took care of those who were categorized as unemployable. As Holmqvist's (2005) and Garsten and Jacobsson's (2013) studies show, such institutions do not depart from the basic regulative logic of disciplinary institutions: they normalize individuals. Yet, as Holmqvist (2005) shows, in sheltered workshops normalization means that the individual is examined, categorized and corrected so that she gradually adopts the identity and behaviour of a disabled person; a person who is normal in a protected environment because she considers herself unfit for work offered by the labour market.

Above, I have shown how basic assumptions of organizational disability studies are valid in the particular context of liberal governmentality and disciplinary regulation. It is in 
that governmental context that those who fail to comply with ableist ideals are treated as disabled and in need of protection and correction (e.g. via sheltered work programs). Below I will begin assessing how these assumptions are affected by the turn towards a neoliberal governmentality and post-disciplinary regulations.

\section{... to neoliberal governmentality...}

Neoliberal governmentality, Foucault suggests (2008), subtly but crucially differs in two respects from its liberal predecessor. First, influenced by scholars like Hayek (1976), Friedman (1982) and Becker (1962), it no longer conceives the market as a natural phenomenon, but as a politically constructed phenomenon, which is essential for the economic and social wellbeing of society. Second, it does not conceive the market as a potential danger to societal solidarity. On the contrary, it points towards the danger of letting activities and individuals be governed according to principles other than those of the market. The institutions of welfare, in particular protective measures like sheltered employment, are therefore seen to be causes of problems such as unemployment and disability rather than their solutions (Becker, 1962; Friedman, 1982; Schultz, 1971).

As general economic stagnation helps these ideas gain political ground in the 1970s, the liberal governmental approach changes: From that of passively protecting the economic rationality of the market while actively compensating for its social ills, to that of resolving social ills (unemployment, disability, etc.) by actively instituting the economic rationality of the market in the whole of society (Donzelot 2008; Foucault 2008; Gordon, 1991). Hence, whereas a liberal governmentality pursues a society of two spheres, neoliberal governmentality pursues a society of one market driven sphere. 
This is important to us here because it implies a new "ableism" (Goodley, 2014), i.e. new ideal individuals and, in that connection, new groups of individuals who are marginalized because they fail to match these ideals. Neoliberal governmentality still idealizes individuals who own and sell themselves as autonomous properties on the market. Yet, as Gershon (2011, see also Martin, 2000) cogently shows, in a throughout market driven society the idealized individual is less and less the autonomous employee, it is the entrepreneur who manages all aspects of her life - her personality, relations, health and lifestyle - as parts of a business (cf. Goodley, 2014).

Gorz (2007), Lazzarato (1996) and Virno (2010) have related these neoliberal ideals to the increasing significance of "immaterial" and "affective labour". Such forms of labour, they argue, are defined by the fact that they are carried out by individuals who make strategic use of their personal characteristics, their humour, their wit, their accents, etc., in order to produce specific cognitive and emotional effects in consumers. Hereby, they argue, such forms of labour not only challenge our conventional understanding of professional skills, they also challenge our understanding of how and where professional skills are formed. Contemporary workers, writes Gorz (2007: 10):

\footnotetext{
... have to come into the production process with all the cultural baggage they have acquired through games, team sports, campaigns, arguments ..., etc. It is in these activities outside work that their liveliness and capacity for improvisation and cooperation have been developed.
}

Hence, Gorz (2007) points out that the specific cognitive and emotional faculties associated with neoliberal ableism (see Goodley, 2014) are products not so much of schooling and professional training, as of individuals' socio-cultural background. A socio-cultural 
background, which comes forth in the form of habits, behaviours, accents, styles, etc., as individuals' "human capital" (Schulz, 1970). That is, as socio-cultural "collections of assets that must be continually invested in, nurtured, managed, and developed" (Martin 2000: 582).

As Munro (2012) and Weiskopf and Munro (2013) point out, this notion of human capital represents the essence of neoliberal ableism. It implies that in a neoliberal society the idealized individual is no longer the nature given exchange partner of classical liberalism, but a trained competitor; an individual who has been taught to relate to herself as a source of her earnings, i.e. as a performance device that she must be able to repair and nurture at will (Munro and Weiskopf, 2013; cf. Goodley, 2014).

Hence, through this idealization of individuals that relate to all aspects of their selves and their lives as human capital, neoliberal governmentality extends a competitive economic grid into the fabric of individuals' existence. This is important to us here because it implies new forms of marginalization. As I show below, new designated impairments develop, which have as their common denominator a lack of social and cultural fit. In a society, I suggest, where all aspects of individuals' lives are treated as human capital, socio-cultural fit becomes a core of individuals' employability. Furthermore, the lack of socio-cultural fit comes forth as impairments - but as we shall see, not necessarily disabilities.

\section{...and post-disciplinary regulation}

As we shall see in the empirical account below, a basic reason why these new designated impairments come forth as abilities rather than disabilities relates to how a neoliberal governmentality also changes disciplinary institutions like sheltered workshops. Foucauldian research is less clear and less developed on how neoliberal governmentality changes disciplinary institutions. Yet, it shows that the neoliberal turn is associated with new forms of 
control, which differ from disciplinary control in two respects: First, they do not situate individuals in closed and controllable spaces (e.g. the factory, the office, the sheltered work shop), and secondly, they do not seek to correct individuals in relation to fixed collective norms. Instead they seek to regulate individuals in the existing milieus where they live, work, consume, socialize, etc (see Author, 2016; Munro, 2012). Furthermore, they define individuals with the intention of making aspects of their existing selves, lifestyles and abilities more useful (Fleming, 2014).

Elsewhere (Author, 2016) I have suggested that Health Promotion programs are examples of post-disciplinary control. Such programs do not situate individuals in a bounded space for the sake of correcting them in relation to collective norms. Rather, they define their lifestyles and help them prioritize among the interests, habits and faculties they already possess so that they can put them together and cultivate them as their human capital. Such programs exemplify Foucault's definition (2007: 44): "whereas discipline is essentially centripetal ... [it] functions to the extent it isolates a space ... it concentrates, it encloses, it is protectionist ... [post-disciplinary regulation] is centrifugal". It seeks to define individuals' existing nature for the sake of making it valuable human capital (Fleming, 2014; Author, 2016).

I suggest the individual placement programs I account for below are examples of such post-disciplinary control. These, as we shall see, make use of examination techniques that designate individuals as impaired, but not to protect them from the market, neither to correct them, but to sell them in the labour market as human capital.

\section{Method}

The account and analysis are based on a 2-year project (2015-2017) examining the organization Samhall's transformation from a sheltered work provider to a provider of 
individual placement programs. Based on Holmqvist's (2005) study of Samhall, undertaken in the early 2000s, I had previous experience from analysing Samhall's Sheltered work programs (Author et al., 2013). As I attended a seminar in 2015 with Samhall representatives I became aware of the organization's new operations. I therefore contacted the CEO of Samhall and was granted access for a study. Via a contact person at Samhall's head office I planned the research, which was divided into four separate fieldworks that took place in four different regions of Sweden: Region Stockholm, Region South, Region Middle-south and Region Middlenorth (Samhall operates in all parts of Sweden). I spent one week in each Region where Samhall has at least one office which serves as "home base" for its' staff and employees.

The study is based on a total of 40 interviews with Samhall's staff (17), Samhall's impaired employees (15) and Samhall's partners (8). The interviews were complemented by a number of onsite observations of work activities, which also involved many short conversations with Samhall's employees, its staff and partners.

In addition to interviews and on-site observations I collected written material consisting of reports issued by the PES (2011: 2018a), government reports (SOU, 2009) and international reports issued by the International labour organization (2015 and the UN (2006). Basically, all reports problematize the current political agenda for marginalized groups in the labour market.

All interviews were purposefully sampled (Corbin and Strauss, 1990) to represent various social, medical and organizational categories - men and women, physically and mentally impaired, senior members and newcomers, staff and employees, etc. Most of the interviews lasted around 40 to 60 minutes and were carried out during the course of the working day. Common ethical guidelines concerning informed consent were followed (Creswell, 2011). All interviewees were informed that they would remain anonymous. There 
was an almost equal split between men (8) and women (7) among the interviewees with designated impairments.

The interviews were open ended. Rather than a fixed set of questions I followed three broad interview guides, one intended for Samhall employees, one for Samhall staff and one for Samhall's partners. I asked Samhall's employees questions about: 1. Their type of assignments and their professional background. 2 . Whether or not the employee is able to handle the job, believes that he or she is suitable for the job and feels that he or she is able to do a good job. 3. What type of impairment the employee is designated with; how the employee understands the meaning of his or her impairment; to what extent the employee accepts it as an adequate description of his or her personal characteristics; how the impairment influences the employee in his or her work and whether or not the employee experiences that the impairment is acknowledged and, in that case, how by partners and Samhall's staff? I asked Samhall's staff questions about: 1. How the transformation from sheltered work to individual placement had changed their work. 2. How they understood the terms impairment and disability and what these terms meant for their abilities to help the employees get jobs; whether or not the meaning of these terms had changed over time? 3. How they assessed the employees' impairments and how they used these assessments when trying to help the employees get jobs. Finally, I asked Samhall's partners questions about: 1 . The type of jobs they give Samhall employees. 2. The reasons for employing Samhall employees. 3. How the Samhall employees are affected by their impairments and how they perform relative to other, non-impaired employees?

I used my previous analysis of Samhall's sheltered work programs (Author et al., 2013) as a point of departure when gathering and analysing data. Hence, my research was guided by the general question: What is the difference between sheltered work and individual 
placement? At the same time, I tried to stay naïve with regards to Samhall's operations. Rather than using a predetermined set of themes and issues, I let themes and issues develop, gradually, as the fieldwork progressed.

The method I used is hereby best described as a combination of a comparative and grounded theory approach (Charmaz, 2006). After having coded the interviews and the onsite observations from the first week of fieldwork in Region Stockholm, the issues the interviewees talked about were grouped in a fairly large number of unsorted themes. As the fieldwork progressed in Region south, Region middle-south and finally in Region middle-north the themes became fewer and more distinct. More specifically, three overarching themes gradually developed as the study progressed: 1 . That Samhall now employs individuals with different types of impairments than before. Mostly, employees' impairments are no longer physical, but mental or social. 2. That Samhall's transformation implies a new approach when assessing the employees' impairments. It still assesses the extent to which its employees' impairments disable them, but it has also begun assessing the extent to which these impairments can be resources and capabilities rather than disabilities. 3 . That Samhall has abandoned its earlier ambition of "rehabilitating" its employees and instead seeks to "match" its employees' existing characteristics against jobs offered on the labour market. In this pursuit a particular type of impaired employee seemed to be idealized; an employee who is content with jobs that non-impaired employees would find unsatisfactory or unacceptable: the docile impaired employee.

A final note on how I use the terms impairments and disabilities. In line with the critical strand of organizational disability studies (Tremain, 2015; Mik-Meyer, 2016; Shakespear, 2006; Thanem, 2008) I use both terms as discursive phenomena, i.e. as terms that operate as structuring, constituting forces, implying and framing individuals' subjectivity and 
practices. When analysing the data, I have thus been especially attentive to how employees with designated impairments, Samhall's staff and its' partners talk about and possibly identify or dis-identify with the notions of "employee with impairments" and "employee with disabilities". I consider both these notions as ambiguous phenomena, which are reproduced, contested and transformed in discursive practices. This, then, is why I consider the study presented below important; it accounts for and analyses actual talk and reflections about these notions and thereby seeks to capture their discursive formation.

\section{Samhall - background}

In most European countries, the neoliberal turn is associated with a gradual sharpening of the distinction between short-term unemployed individuals and long-term unemployed individuals (Bengtsson and Berglund, 2012). Among the latter category there has been a considerable increase of individuals who are coded as impaired (Author et al., 2013; Foster and Wass, 2013; Holmqvist, 2009; Lindsay et al., 2014; Vanderkinderen et al., 2012). The Swedish labour market is here a case in point. The number of long-term unemployed who are coded as impaired has increased by approximately $400 \%$ since the early 1990 s. Today approximately $60 \%$ of the long-term unemployed are diagnosed with some form of impairment (Public Employment Office, 2018a).

In Sweden, the Public Employment Office (henceforth PEO) has a special mission to support unemployed individuals who are designated as impaired by integrating them in the labour market. This ambition is meant to meet the new ILO (2015) and UN-conventions on "the rights of Persons with disabilities" (UN, 2006). In alignment with the transformation from liberal to neoliberal governmentality I outlined above, these conventions emphasize that impaired individuals should not be sheltered from the labour market, but have a "right to the 
opportunity to gain a living by work freely chosen or accepted in a labour market" (UN, 2006, article 27).

Samhall is the largest of a range of social enterprises whose business it is to integrate impaired individuals in the labour market. Samhall is owned by the Swedish state and is with its 27000 employees the largest employer of impaired individuals in Scandinavia. Apart from managers and staff, Samhall only employs individuals who are coded by the PEO as impaired. PEO's impairment coding is handled by a staff of specialists who are either "work life psychologists", "occupational therapists" or "social welfare supervisors". Jobseekers are sent to these professionals when a PEO staff "suspects" that the reason for a jobseeker's inability to get employment is a not yet classified impairment. Generally, long-term unemployment is seen as a "sign" of a potential impairment. Thereby, the majority of long-term unemployed individuals are investigated by the PEO specialists (Garsten and Jacobsson, 2013; Holmqvist, 2009). These professionals perform so-called (1) "work life psychology investigations", (2) "activity-based investigations" and (3) "work-related social investigations". These are standardized tests developed by PEO (2011), which map and analyse (1) the jobseeker's lifestyle, (2) the jobseeker's physical and psychological abilities (walking, lifting, staying focused, reading, writing, etc.) and (3) the jobseeker's social conduct (communicating, socializing, etc.). Through these tests they determine which type of impairment code (if any) a jobseeker should be given (PEO, 2018a). There are three general impairment codes. These are: "physical impairments", "psychological impairments" and "socio-medical impairments" (PEO, 2018a; see also Garsten and Jacobsson, 2013). The codification of a jobseeker as physically impaired can only be made by a medical expert. Yet, the codification of jobseekers as psychologically or socially-medically impaired can be handled by any of PEO's three categories of professionals without the support of further medical expertise (see Garsten and 
Jacobsson, 2013). Yet, jobseekers have to accept the impairment classifications for them to be lawful. Several of the Samhall employees that I interviewed emphasized that initially, they had not accepted or understood their impairment classification. Yet, the fact that they are only entitled to employment, for instance at Samhall, provided that they are coded as impaired, made them change their minds. As said by one Samhall employee: "When you realize that the ticket out of unemployment is an impairment code, you accept it."

\section{From sheltered employment and disciplinary regulation to...}

Samhall's mission is to "create jobs, which are developing for individuals who have impairments". From the mid 1970s, when Samhall was inaugurated, up until the early 2000s, this meant that it gave impaired jobseekers sheltered employment. The goal was to "rehabilitate" these individuals so that they later would be able to enter the labour market (Holmqvist, 2005). Yet, around 2002-2003 it did not achieve this official goal. Only $2 \%$ of the individuals that were helped to sheltered employment got employment in the labour market. In fact, rather than helping employees develop competencies and self-esteem so that they eventually could leave Samhall, Holmqvist (2005) showed how Samhall's sheltered work programs made the employees see and conduct themselves as disabled and unemployable individuals.

Holmqvist's (2005) results are well aligned with a liberal governmentality and disciplinary regulation and with the basic assumptions of organizational disability studies. They show that individuals who were unable to meet employability ideals were categorized as "disabled" and sheltered from the labour market for the sake of protecting and correcting them. Once at Samhall, the study shows, meticulous examinations were used to discipline the employees so that they first accepted that they were in fact disabled and second, so that they 
conducted themselves as "normal impaired employees" do. That is, as disabled employees, working slowly with low performance expectations.

\section{...to post-disciplinary management of human capital}

Since the turn of the century much have changed. First and foremost, the sheltered workshops are now gone. In their place Samhall has developed "individual placement programs", which are meant to give the employees jobs in the labour market. The programs are built around regionally structured networks of partner firms such as Ikea, McDonalds, Burger King, Jernhusen (Real estate), etc. Samhall satisfices these firms' needs of simple service or factory labour such as cleaning, laundry services, manual packaging, manual warehouse work, etc. by renting out its impaired employees on a short-term contractual basis.

The change from sheltered work programs to individual placement programs is related to three principle transformations of Samhall's operation, which I touched upon above and account for below: 1. Employees with physical impairments have become fewer while those with social-psychological impairments have become more numerous. 2. Employees' impairments are assessed with regards to how they enable (rather than disable) employees. 3. A particular type of impaired employee is idealized because this employee is content with jobs that non-impaired employees would find unacceptable: the docile impaired employee.

\section{From physical to social-psychological impairments}

The turn towards individual placement programs are closely related with a change in the types of impairments that the employees are designated with. A long-term staff at Samhall explains: 
A couple of decades ago most people who worked here were physically impaired. That has changed. Now, the majority of our employees have impairments, which are difficult to see. This is because their impairments have more to do with their social skills and appearance than with physical issues.

Another staff-member explained that:

Gradually, as the sheltered work-shops have been replaced by individual placement programs, the performance expectations on part of our employees have increased, sometimes considerably. Therefore, many of the impaired individuals that Samhall once provided with jobs cannot match the new performance criteria.

Hence, while you have to be designated as impaired to be allowed to work for Samhall, nowadays you also have to be able to perform at a high level. Individuals with physical impairments have therefore become quite rare presences at Samhall.

Generally, the prevalence of employees categorized as "psychologically impaired" and "socio-medically impaired", has increased considerably. One of Samhall's staff elaborated what this means. She said:

The most common psychological impairment is "specific learning impairment". To get this code you must have taken a test at the PEO [PEO, 2008a or 2008b]. Yet, the coding procedure is more profoundly based on PEO staff's conversations with the clients. I mean, to be able to get a job these days, individuals have to be able to look people in the eyes and they need to be able to adapt and learn new things. If jobseekers are socially incompetent, the PEO's staff will notice that in their conversations with the jobseekers, and they will typically list that incompetence as "lack of empathy", "lack of 
communicative skills", and the like. What this means is basically that the jobseekers are likely to have problems unless the work they are given is relatively free from social interaction.

Especially interesting is the code "social-medical impairment". This code is explained to be used for employees, who have no physical impairments, but, as stated by a Samhall staff, "where their physical presence still makes it problematic for them to work in public spaces". He continued:

Some people might have a record of drug abuse. Others might have done time in prison. These people have led lives, which have left marks. You can literarily see it on them, in their starring eyes, in their faces, which are full of wrinkles from a hard life or on their hands and arms that might be full of illmade tattoos. And you see it when they move. Their body-language gives them away, as it were.

Hence, individuals who are coded as having "social-medical impairments" are neither physically impaired, nor psychologically impaired. Yet, they are nevertheless considered to have permanent physical or behavioural characteristics, which hinder them from getting employment.

\section{Assessing impairments - from disabling to enabling}

The turn towards individual placement programs has also fundamentally changed how Samhall assesses and makes use of the employees' impairments when trying to find jobs for the employees. The first step in the processes of finding a job for the newly appointed Samhall employee is the so-called "assessment of the employee's general work capacity" (AWC). One of Samhall's staff explained: 
The three general categories of impairments are defined in relatively broad terms. Yet, they give us a preliminary understanding for the type of jobs that the employees are or are not suitable for. For instance, if one of our partners has a need for a person that can work in a concierge desk, we do not start looking for that person amongst the employees that have social-medical impairments.

The AWC is handled by an occupational therapist and consists of a series of tests of the employee's physical, mental and social abilities. This involves questionnaires, interviews and specific exercises, which are meant to determine the employee's abilities, physically, mentally and socially in concrete and observable terms. The AWC results in an estimation of the employee's general capacity to carry out work. $50 \%$ work capacity means that an employee is estimated to be able to work half as efficiently as a "normal" employee does. Strategic partners who buy such an employee's services from Samhall hereby pay only $50 \%$ of the employee's wage; the rest is paid by Samhall.

The second step in finding a job for the employee is based on an "assessment of the employee's work performance" (AWP). This assessment is also handled by an occupational therapist. In the AWP, the focus is not on the employee's general capacities to work, but on the extent to which the employees' characteristics match the specific performance criteria of the jobs offered by Samhall's strategic partners. While the employee's impairment code is used as a point of departure in these "matching procedures" it was emphasized by Samhall's staff that:

It is important to point out that when we do these qualitative descriptions of the employees' characteristics [AWP] we do not investigate in which respects their impairments hinders them from 
working efficiently. Quite the contrary, we investigate where the employees' specific characteristics, including their impairments, are assets rather than liabilities.

The head of the so-called Region South developed these ideas further. She said:

Before the employees come here, they have been investigated over and over again in ways, which are negative, as it were. What I mean is that PEO or some medical expert have focused on their impairments in terms of what they are unable to do. We also focus on their impairments in the AWCs, but after that we turn things around. In the AWPs we ask - how can we make this person useful, not in spite of the fact that he or she is impaired, but precisely because he or she is impaired?

Hence, while the AWC (i.e. the assessment of the employees' work capacity) seeks to estimate in percentage how much the employee's impairment reduces his or her general productivity, the AWP (i.e. the assessment of the employee's potential performance in a specific job) seeks to determine where the employee's specific characteristics - as signalled by the impairment code - make him or her especially valuable.

The two tests hereby point in opposite directions. The first takes for granted that an impairment is more or less disabling and should result in a wage discount. The other, however, relates to the impairment, not as a disability, but as a description of personal characteristics, which are assets if they are "matched" skilfully by Samhall's staff against available jobs. Should we thus conclude that the "individual placement programs" have made Samhall's operations contradictory and possibly even hypocritical?

A Samhall staff discussed this issue. He said: 
The two types of assessments [AWC and AWP] express two different ways of relating to impairments. The AWC views impairments as more or less disabling in relation to general employability ideals. The ideal employee should be active, social, self-controlled and so on. Yet, at the same time there are other less sophisticated jobs, jobs where impairments can also be enabling. Not in relation to general employability ideals, but in relation to the requirements of these specific jobs. This is what the AWP investigates.

This quote suggests not only that the taken for granted connection between designated impairments and disabilities, which is expressed by the AWC, is a trace from Samhall's past as a provider of sheltered employment. It also suggests that impairments are treated at once as disabling and enabling. Disabling in relation to general employability ideals (AWC). Enabling in relation to the specific requirements of less prestigious jobs (AWP). As explained by staff member at Samhall:

Before "individual placement" and "matching" our task was to rehabilitate the employees so that they could, potentially, compete for jobs with normal jobseekers. In truth that was a too ambitious undertaking. Matching is less ambitious. It is basically a matter of mapping the employee with regards to her impairment, personal characteristics, professional experience, motivation and so on and then relate all of that to relatively simple jobs like cleaning, manual packaging, etc.

The CEO of Samhall explained why this new way of relating to the employees' impairments is a win-win for all parties involved:

Samhall's transformation from a provider of sheltered employment to a provider of human resources for hire is a win-win both for our employees and for our partners. Our employees get real work again 
after long periods of unemployment or sheltered employment, which have left them with very low self-esteem. Our partners get access to employees who are loyal, motivated and in many ways better equipped to do their work than normal employees. Furthermore, our partners often see their cooperation with Samhall as part of their Corporate Social Responsibility work. We help them do the right thing and to communicate that both inside and outside their organizations.

\section{Idealizing the docile impaired employee}

Why are Samhall employees "better equipped ... than normal employees" to do the type of work they are given? A customer representative at Ikea explained:

If, for example, we would hire young unemployed people, they would probably get restless and they would not stay on the job for long. Employees from Samhall work harder and are more motivated. Many of them have had a hard time in the past. They have not fitted in. They fit in here, though. We give them substantial jobs. They clean our stores. It is an important job. Yet, it is a routine job where they do not have to interact with people they are unfamiliar with.

Another customer representative at a real estate firm expressed a similar view. She said:

Samhall employees are often excellent when it comes to performing simple and monotonous jobs such as cleaning. You and I would probably not like those jobs. But they do. They take pride in what they do and they do it well.

A Samhall employee working as a cleaner at IKEA said: 
I have been down and out, an unemployed drug addict. You know, when you don't have a job and every time you apply for one, you get a No! you eventually feel completely useless. My impairment classification is "Social-medical impairment". What does it mean? I don't really know. But I think it is simply me. It's what I am, what I have become, a misfit, if you will. But, you know, here, as part of a team of cleaners, I am spot on. We are all misfits, in a way, and that's no problem. Quite the contrary, for you know, most people wouldn't want to do our jobs. When you are out there, in the cold, you realize that just having any job is a good thing. That is why I do this job better.

Basically, the idea is that Samhall employees' impairments come forth as a general lack of adaptability and social competence. In particular, the employees are seen to lack social skills. However, these shortcomings, formally described as "social-medical impairments", "specific or general learning impairments" and the like, are also alleged to be valuable assets. Mainly because they make the Samhall employees docile and therefore able to handle jobs that would make other - "normal" - workers restless, careless and discontent. A staff at Samhall elaborated this point. She said:

... our employees' basic impairment is that they do not know how to behave. It is as simple as that. But knowing how to behave is not easy - our employees are proof of that. So, what are we to do? Well, we try to find jobs where their inabilities are in fact not inabilities, but characteristics, which are useful.

The general impairment that the Samhall employees are seen to have is an inability of knowing "how to behave". Such an impairment is seen to be an asset in manual and monotonous service or factory labour. Valuable, because it is seen to make Samhall employees satisfied with jobs that "normal employees" would find highly unsatisfactory. 
That said, even jobs that are categorized as "simple" often turn out to require social abilities of sensing "how to behave". A customer representative at a real estate firm said:

\begin{abstract}
Many of our buildings are shopping gallerias, railway stations and so on, i.e. buildings with large public areas. The job that the Samhall employees do is very simple. It is to clean toilettes and to drive a cleaning machine over the floors. On the one hand, Samhall employees are perfect for this type of work because they like it and hold on to it as something, which is truly their territory. Yet, on the other hand, that can also be a problem. They tend to do their work too well. For example, if someone drops a piece of litter on the floor in a galleria, a Samhall employee might go and tell that person that he or she has done wrong and should pick it up. You know, in principle they are right, yet you do not treat customers like that - especially not if you are the cleaner.
\end{abstract}

A Samhall employee (diagnosed with dyslexia and coded by the PEO as having a "specific learning impairment") working in the packaging area in a factory, discussed the same issue. He said:

The reason I have not been able to keep jobs has not got anything to do with dyslexia or the impairment code that PEO gave me. I mean there are plenty of jobs where you do not have to write and read so well. For example, I tried to work at McDonalds once, selling burgers. For most people, it is an easy job. You do not have to be educated or anything. Not for me, though. I mean you have to look nice and smile, be able to listen without staring or looking away. I am not good with people. That is the problem, I think. ... So, I guess I am cut up for what I do here at Samhall. I have learned to accept that. 
A Samhall employee working as a garment printer (printing brand names on uniforms, work ware, etc.) in a factory discussed his background and how he has come to accept and welcome his impairment code "social-medical impairment".

For a long time, I was angry. Angry because there were no jobs, angry because the PEO could not help me, angry because I thought that the impairment code [social-medical impairment] was just their excuse for not being able to find me a job. Eventually I gave up. I have worked here [via Samhall] in this factory for two years. And you know, I am no longer angry. I am appreciated here. I do not really understand the impairment code, but I think it says that I am different. It is not anyone's' fault, not even mine. It is just what I am.

Another Samhall employee voiced a similar opinion: He said:

I have always been restless and anxious. ... I did not do well in school, started doing drugs as a teenager and could never hold on to any jobs. ... At first, when the PEO wanted to send me to a medical specialist I just thought it was ridicules. I thought - there is nothing wrong with me, apart from the fact that I ... grew up in useless family. Now I see things differently. Now I understand it was never my fault ... I have ADHD, it makes me restless and it makes me do foolish things. That explains it. But ADHD can also be a good thing if you learn to control it. You should be proud of your ADHD, it is force of nature; it is something that makes you unique and that you can learn to make use of. I have been taught to do so here, I think.

Holmqvist's (2005) study of Samhall's sheltered work programs showed that the employees were taught to accept and openly declare that they were disabled; that they came up short, 
did not cope, etc. In the study accounted for above, employees are examined and designated as impaired. Yet, they are taught that their impairments are strengths and resources in the type of jobs that they perform. In fact, according to Samhall's new philosophy there are no disabled people, only impaired and non-impaired people. Impaired people are seen to have specific short-comings, which, however, are also specific strengths, if properly matched against jobs offered in the labour market. An employee working as a cleaner, expresses this clearly. She says:

I have Asperger. It can be a good thing, sometimes. That is what we are taught at Samhall, that our impairments make us more employable, if we just find the job that we are made for. I clean the stores, that is the job for me, it's what I am made for.

With the new individual placement regime, employees learn that they are impaired, but not disabled, that they do not need shelter and "rehabilitation", but "matching". They learn that there is a place for them in the market; a place that is truly theirs because it fits "their nature". Samhall's staff is proud of the new regime. Proud because it reveals their employees' strengths whereas the old regime revealed their weaknesses (disabilities).

Yet, whereas the old regime assumed that impaired individuals could change and could, potentially, do just any job if they were given proper help, the new regime assumes that individuals with designated impairments cannot change and are destined for jobs that non-impaired individuals would not do.

\section{Discussion}


I have used the study of Samhall's "Individual placement program" as an example of how a neoliberal governmentality changes the meaning, evaluation and regulation of impaired jobseekers. The study illustrates how a neoliberal governmentality gives rise to a new type of ableism: The idealization of individuals capable of nurturing their personalities and sociocultural skills as their human capital results in that more and more jobseekers who do not match this ideal are constructed as psychologically or socio-medically impaired. Furthermore, the study shows how the fact that these jobseekers are constructed as impaired does not lead to that they are regulated as disabled; they are regulated as impaired and able rather than impaired and disabled. It is in this particular respect that the individual placement program comes forth as an example of post-disciplinary regulation: rather than sheltering and thereafter correcting impaired jobseekers in relation to collective norms, it defines and categorizes them for the sake of turning their impairments into human capital, which can be sold in the labour market. I will elaborate these points below and show how they relate to existing organizational disability studies.

\section{Constructing impaired jobseekers by medicalizing their lack of socio-cultural fit}

The study shows how neoliberal governmental reforms, which emphasize integration in the labour market rather than shelter from the labour market for jobseekers with impairments, have had profound effects. Firstly, on the type of impaired jobseekers that Samhall employs. The account shows that the majority of Samhall's employees in the late 1990s and early 2000s were coded as physically impaired. Now, however, the majority of its' employees are coded as having "specific learning impairments" or "social-medical impairments". These impairment codes do not refer to employees' permanent lack of physical abilities of carrying out specific material tasks, but to their perceived lack of socio-cultural skills and competencies. We saw 
that the employees are considered impaired by the PEO and Samhall's staff because of their lack of abilities of communicating face-to-face with a proper tone of voice and without starring or locking the other way, because of their improper bodily language, etc.

In this sense, Samhall's employees are considered impaired because they lack the "soft" skills required to carry out "immaterial labour" and "affective labour" (Lazzarato, 1996, Gorz, 2007). That the lack of "soft" skills is designated as an impairment represents the other, darker side of a neoliberal governmentality. It shows how the idealization of the entrepreneurial self has come to imply abilities of "optimizing life in accord with ... the existence of individual free enterprise" (Dean, 2015: 19). When the idealized employee is no longer someone that first and foremost brings the right professional skills to work, but the right lifestyle, personality and set of socio-cultural skills (Martin, 2000), the case suggests that the lack of such socio-cultural fit becomes "medicalized" (Conrad, 1992; Holmqvist, 2009).

Hence, one primary consequence of Samhall's transformation from a provider of sheltered employment to a provider of individual placement programs is the medicalization of jobseekers who lack the proper socio-cultural skills. The case hereby provides empirical support to the thesis put forth by critical disability studies (Author et al., 2013; Holmqvist, 2009; Shakespear, 2006; Thanem, 2008; Tremain, 2015), namely that we need to pay closer attention to the ontological status of impairments; how not merely disabilities, but also impairments are subject to social construction in relation to political goals.

Judging from the account, the basic driving force of this medicalization process is the 'political economy' that it establishes where all parties involved - the PEO, Samhall, customers/partners to Samhall, and the impairment coded jobseekers - appear to have something to gain. By coding jobseekers as impaired, the PEO gets to assign jobseekers to social enterprises like Samhall, which are only entitled to employ jobseekers that have 
impairments. Hereby the PEO can report lower unemployment levels and also that it cares and takes responsibility for marginalized jobseekers. Samhall, in turn, receives employees (for whom they are financially compensated by the Swedish state) that it can contract out to its customers/partners. These customers/partners to Samhall get access to subsidized labour power that are described as more suitable than "normal" employees to handle the tasks they are given. Finally, the marginalized jobseekers are not only provided with employment, but also with opportunities of not having to take responsibility for their past 'failures' (of getting a job) that comes with an impairment diagnosis.

\section{$\underline{\text { Turning impairments into abilities and human capital }}$}

The second major consequence of Samhall's transformation from a sheltered employment provider to a provider of individual placement programs concerns how it evaluates and makes use of its employees' impairment codes. As recalled, up until the early 2000s Samhall assessed the employees' impairments with regards to how they disabled the employees (Holmqvist, 2005; Author et al., 2013). In fact, well aligned with the social model of disability's general argument (Oliver, 1990) that the connection between individuals' impairments and their disabilities is socially constructed, Samhall's sheltered employment regime was found by Holmqvist (2005) to discipline its employees so that they gradually adopted an identity as disabled and acted accordingly. That is, it constructed a causality between the employees' designated impairments and specific disabilities. This, Holmqvist (2005) shows, was not an unintended consequence. It was a result of that it was only legitimate for Samhall to keep the employees in sheltered employment provided that they were 'in fact' disabled.

Yet, as Samhall has been transformed into a provider of individual placement programs this logic has been turned upside down. Via the AWC test it still assesses the 
employees with regards to how much their impairments disable them. Yet, as it no longer seeks to rehabilitate the employees in relation to general employability ideals, but merely seeks to turn the employees into valuable resources for its customers, the AWC tests are used just to legitimise a wage discount. With regards to specific job offerings, Samhall makes use of the AWP test to assess the impairments in the opposite sense, namely as templates, which indicate in which regards the impaired employees have a specific fit. Differently put, rather than as signals of disabilities, the AWP test treats impairment codes as indications of specific abilities.

Hence, whereas the sheltered work programs constructed a causality between employees' impairments and specific disabilities, the individual placement programs construct a causality between employees' impairments and specific abilities. The reason for this turnaround is obvious. Rather than having to construct its' employees as disabled to keep them sheltered, it now needs to show in which specific respects its' employees are fit to handle the jobs that Samhall's partners offer.

\section{Conclusions}

The study has illustrated how impairments are socially constructed in relation to politicaleconomic ends. As such it has provided empirical support to the thesis developed in critical disability studies, namely that not only disabilities, but also impairments are subject to social construction (cf. Goodley, 2014; Holmqvist, 2009; Thanem; 2008; Tremain, 2015). In that connection, the study has shown that we have reason to question the assumption underlying the majority of organizational disability studies, namely that individuals with designated impairments come forth as disabled and are regulated as needy of protection and correction. This assumption, I have shown, relates to a liberal governmentality and disciplinary forms of 
regulation such as sheltered workshops. The turn to neoliberal governmentality, the study shows, is associated with a new ableism and post-disciplinary forms of control such as individual placement programs. These do not protect impaired individuals from the labour market. Neither do they seek to correct them. Instead they seek to turn individual's designated impairments into human capital, which is immediately valuable in the labour market.

Given that the new neoliberal governmental approach constructs jobseekers as impaired and able and seeks to integrate them in the labour market, do we still have reason to question its' moral implications? The analysis above shows that the answer to that question is yes! As we have seen, that impaired employees are treated as able rather than disable does not mean that they are treated as non-impaired employees' equals. Quite the contrary, we have seen how their designated impairments are used as templates signalling that they fit in and are useful precisely where non-impaired individuals are not. Just like Fredric Taylor (2004) famously treated "Mr Schmitt" as especially fit to handle "pig iron" because his mental capacities were such that he did not get bored from doing monotonous and simple labour, Samhall treats its employees as especially fit to handle monotonous jobs, precisely because they are impaired.

Neoliberal governmentality and post-disciplinary controls hereby open a sphere of existence for impaired individuals, which places them at once inside and outside society. Inside, because the process (the individual placement program) in which their impairments are translated into human capital gives them "real jobs" offered by the labour market. Outside, because the same process makes them divided from others and divided within themselves; it turns them into impaired outsiders who are considered by the labour market 
and, eventually, also by themselves as fit for jobs than non-impaired individuals would not accept.

In this respect, the impaired employees of this study constitute a new version of the "docile individual" found in the early liberal era's crude factories. Foucault describes this individual as a "machine ... something that can be made; out of a formless clay" (1977, p. 135); an individual who becomes "more obedient as it becomes more useful, and conversely" (1977, 138). The jobseekers of this study are not fabricated by factory discipline, but by a medicalization process. Yet, the end result is similar. The more subjected they are to their impairment categorization, the more useful they become.

This, I suggest, is the mixed blessing of a neoliberal governmentality and postdisciplinary regulations: they open up possibilities to get jobs in the labour market for jobseekers with designated impairments. Yet, in so doing, they push them towards the fringes of the labour market where they come forth as bio-medically fit for jobs that no one else wants.

\section{References}

Abberley, P. (2002). Work, disability, disabled people and European social theory. Disability Studies Today, Polity Press, Oxford.

Albrecht, G. (1992). The Disability Business: rehabilitation in America. London: Sage. Arbetsförmedlingen (2011) Handläggarstöd, bedömning av arbetsförmåga Arbetsförmedlingen (2018a) Översyn av termen nedsatt arbetsförmåga Arbetsförmedlingen (2018b) Handläggarstöd. Bidrag till hjälpmedel på arbetsplatsen Barnes, C., Mercer, G. (2005) (Eds.), Exploring the divide: chronic illness and disability. Leeds: The Disability Press. 
Becker, G. 1962. "Investment in Human Capital: A Theoretical Analysis." The Journal of Political Economy 70 (5): 9-49.

Bengtsson, M., Berglund, T. (2012) Labour market policies in transition: From social engineering to standby-ability, in Larsson, B. et al. (eds) Transformations of the Swedish Welfare State, London, Palgrave Macmillan

Campbell FK (2001) 'Inciting legal fictions: Disability’s date with ontology and the ableist body of the law'. Griffith Law Review 10(1): 42-62.

Campbell F. (2008) 'Exploring internalized ableism using critical race theory'. Disability and Society 23(2): 151-162.

Campbell F. (2009) Contours of Ableism: The Production of Disability and Abledness. Basingstoke: Palgrave Macmillan.

Charmaz, K. (2006). Constructing grounded theory: A practical guide through qualitative analysis. Sage.

Chouinard, V. (1997). Making space for disabling differences: challenging ableist geographies. Environment and Planning D: Society and Space, 15, 379-390.

Conrad, P. (1992). 'Medicalization and social control'. Annual review of Sociology, 18(1), 209232.

Corbin, J. and Strauss, A. (1990). Grounded theory research: Procedures, canons, and evaluative criteria. Qualitative sociology, 13(1), 3-21.

Colella, A. and Stone, D. (2005) "Workplace discrimination toward persons with disabilities: A call for some new research directions." Discrimination at work: The psychological and organizational bases: $227-253$.

Covaleski, M., Dirsmith, M., Heian, J., and Samuel, S. 1998. “The Calculated and the Avowed: Techniques of Discipline and Struggles over Identity in Big Six Public 
Accounting Firms." Administrative Science Quarterly 43 (2): 293-327.

Dean, M. (1999) Governmentality. John Wiley \& Sons, Ltd, 1999.

Dean, M. (2015) "The Malthus Effect: population and the liberal government of life." Economy and Society 44 (1): 18-39.

Dean, M., \& Villadsen, K. (2016). State phobia and civil society: The political legacy of Michel Foucault, Stanford, CA: Stanford University Press.

Donzelot, J. (2008) “Michel Foucault and Liberal Intelligence." Economy and Society 37(1): 115-134.

Foster, D., and Wass, V. (2013) "Disability in the labour market: An exploration of concepts of the ideal worker and organizational fit that disadvantage employees with impairments". Sociology 47(4): 705-721.

Fleming, P. (2014) "Review Article: When 'life itself' goes to work: Reviewing shifts in organizational life through the lens of biopower." Human Relations 67 (7): 875-901. Friedman, M. (1982) Capitalism and Freedom. Chicago: The University of Chicago Press.

Foster, D., \& Wass, V. (2013). Disability in the Labour Market: An Exploration of Concepts of the Ideal Worker and Organisational Fit that Disadvantage Employees with Impairments. Sociology, 47(4), 705-721.

Foucault, M. (2003) Society Must Be Defended: Lectures at the Collège de France. London: Picador.

Foucault, M. (2007) Security, Territory, Population: Lectures At The Collége de France, 19771978. London: Picador.

Foucault, M. (2008) The Birth Of Biopolitics: Lectures At The Collége de France, 1978-1979. London: Picador. 
Garsten, K. and Jacobsson, K. (2013) 'Sorting people out: The plasticity of the categories of employability, work capacity and disability as technologies of government, ephemera - theory and politics in organization, Vol. 13 (4), 825-850.

Gershon, I. (2011) “Neoliberal Agency.” Current Anthropology 52 (4): 537-555.

Goodley, D. (2014). Dis/ability studies: Theorising disablism and ableism. Routledge.

Gordon, C. (1991) "Governmental rationality: an introduction." In Burchell, Graham, Gordon, Collin, Miller, Peter (eds) The Foucault effect: Studies in governmentality, Chicago: The University of Chicago Press.

Wester, K. L. (2011). Publishing ethical research: A step-by-step overview. Journal of Counselling \& Development, 89(3), 301-307.

Gorz, A. (2007) The Immaterial, London, Seagull books

Hayek, F. (1976) Law, Legislation and Liberty - The Mirage of Social Justice. New York: Routledge Keagan and Paul.

Holmqvist, M. (2005) Samhall: Att bli normal l en onormal organisation. Lund: Studentlitteratur.

Holmqvist, M. (2009). Medicalization of unemployment: individualizing social issues as personal problems in the Swedish welfare state. Work, employment and society, 23(3), 405421.

Holmqvist, M., Maravelias, C., P. Skålen (2013) 'Identity regulation in neo-liberal societies: constructing the "occupationally disabled" individual, Organization, Vol 20 (2), 1-19. Hochshild, A. (1983) "The managed heart." Jaggar, Alison and Paula Rothenburg 3 ILO (2015) ILO and Disability Inclusion 
Jammaers, E., Zanoni, P., Hardonk, S. (2016) "Constructing positive identities in ableist workplaces: Disabled employees' discursive practices engaging with the discourse of lower productivity." Human Relations 69 (6): 1365-1386.

Lazzarato, M. (2009) "Neoliberalism in action inequality, insecurity and the reconstitution of the social." Theory, Culture \& Society 26 (6): 109-133.

Lindsay A, Adams, T., Sanford, R., McDougall, C., Kingsnorth, S., Menna-Dack, D. (2014) “Employers and employment counsellors' perceptions of desirable skills for entry-level positions for adolescents: How does it differ for youth with disabilities?" Disability and Society 29(6): 953-967.

Martin, E. (2000) “Mind-body problems". American Ethnologist 27 (3): 569-590.

McNay, L. (2009) "Self as Enterprise: Dilemmas of Control and Resistance in Foucault's The Birth of Biopolitics." Theory Culture Society 26 (6): 55-77.

Miller, P. and Rose, N. (2008) Governing the Present: Administering Economic, social and Personal Life.

Mik-Meyer, N. (2016). Othering, ableism and disability: A discursive analysis of co-workers' construction of colleagues with visible impairments. Human Relations, 69(6), 1341-1363. Munro, I. (2012) "The Management of Circulations: Biopolitical Variations After Foucault." International Journal of Management Reviews 14 (3): 345-362.

Munro, I. and Weiskopf, R. (2013) “Management of Human Capital: Discipline, Security and Controlled Circulation in HRM". Organization, 19(6): 685-702.

Oliver, M. (1990) "The politics of disablement: A sociological approach. New York: St. Rose, N. (1996) Inventing Ourselves: Psychology, Power and Personhood. Cambridge: Cambridge University Press. 
Rose, N. (1999) Powers of Freedom: Reframing Political Thought. Cambridge: Cambridge University Press.

Rose, N. (2007) The Politics of Life Itself: Biomedicine, Power and Subjectivity in the $21^{\text {st }}$ century. Princeton: Princeton University Press.

Shakespeare, T. (2006). Disability rights and wrongs. Routledge.

Schultz, T. (1971) Investment in Human Capital: The Role of Education and of Research. New York: The Free Press.

Smith, A. (1977/1776) The Wealth of Nations. Chicago: The University of Chicago Press.

SOU (2009: 89) Gränslandet mellan sjukdom och arbete

Stone, D. L., \& Colella, A. (1996). A model of factors affecting the treatment of disabled individuals in organizations. Academy of management review, 21(2), 352-401.

Taylor, F. W. (2004). Scientific management. Routledge.

Thanem, T. (2008) "Embodying disability in diversity management research." Equal Opportunities International 27 (7): 581-595.

Thomas, C. (2004). ‘How is disability understood? An examination of sociological approaches'. Disability \& society, 19(6), 569-583.

Townley, B. (1994) Reframing Human Resource Management: Power, Ethics and the Subject at Work. London: SAGE Publications Ltd.

Tregaskis, C. (2004). Constructions of disability: Researching the interface between disabled and non-disabled people. Psychology Press.

Tremain, S. (2015). Foucault and the Government of Disability. University of Michigan Press. UN (2006) Convention on the Rights of People with Disabilities 
Vanderkinderen, C., Roets, G., Vandenbroeck. M (2012) ‘One size fits all? The social construction of dis-employ-abled women. Disability and Society' 27(5): 703-716.

Williams, J. and Mavin, S. (2012) ‘Disability as constructed difference: A literature review and research agenda for management and organization studies'. International Journal of Management Reviews 14(2): 159-179. 